\title{
Modifications in phytoplankton size structure by environmental constraints induced by regime shifts in an urban lake
}

\author{
Martin T. Dokulil · Karl Donabaum • \\ Katrin Teubner
}

(C) Springer Science+Business Media B.V. 2007

\begin{abstract}
Size related changes of phytoplankton biovolume and species composition have been analysed for forward and reverse regime shifts in a shallow, urban, seepage lake. As a consequence of changes in the hydrology, the pelagic switched from a clear water, macrophyte dominated state to a turbid stable phase with an abundant cyanobacterial population. Experimental nutrient reduction forced the system into a recovery phase. Each state change was associated with significant changes in total biovolume, species composition and size structure affecting surface to volume ratios $(\mathrm{S} / \mathrm{V})$. Chlorophyll- $a$ content and $\mathrm{S} / \mathrm{V}$ drastically increased during the early recovering phase due to small cell sized species developing. As expected, state transitions were
\end{abstract}

Guest editors: M. Albay, J. Padisák \& L. Naselli-Flores Morphological plasticity of phytoplankton under different environmental constraints.

M. T. Dokulil $(\varangle) \cdot$ K. Teubner

Institute for Limnology, Austrian Academy of

Sciences, Mondseestrasse 9, 5310 Mondsee, Austria

e-mail: martin.dokulil@oeaw.ac.at

K. Teubner

e-mail: katrin.teubner@oeaw.ac.at

\section{K. Donabaum}

Donabaum \& Wolfram OEG, 1040 Wien, Buro for

Ecology, Zentagasse 47, A-1050 Vienna, Austria

e-mail: karl.donabaum@donabaum-wolfram.at associated with significant alterations in size structure and composition.

Keywords Allometry - Stable states · Restoration - Surface volume ratio . Shallow lake

Allometric scaling and size related community structure has been established for a wide variety of processes in phytoplankton from both marine and fresh-waters (e.g. Moloney \& Field, 1989; Lewis, 1977; Nielsen \& Sand-Jensen, 1990; Joint, 1991; Shkundina, 1991; Teubner \& Dokulil, 2000; Havlicek \& Carpenter, 2001; Finkel et al., 2004). Here we demonstrate changes in biovolume, species composition and related size structure during ecosystem state change.

Data originate from a shallow urban lake, Alte Donau, in Vienna, Austria. Hydrological changes induced a forward switch from a macrophyte dominated clear water system to a turbid, algal controlled phase in the early 1990s. Internal restoration measures forced the system back to the original stable state (Dokulil et al., 2000, 2006; Donabaum et al., 2004).

Nutrient reduction by internal phosphorus flocculation in early 1995 and 1996 drastically reduced total phosphorus concentration (TP) from an annual average of $70 \mu \mathrm{g} \mathrm{l}^{-1}$ in 1994 to less than $20 \mathrm{~g} \mathrm{l}^{-1}$ (Dokulil et al., 2000). Concomitantly phytoplankton total biovolume 
Fig. 1 Development of variables in Alte Donau from 1993 to 2000 . From top to bottom: Percentage contribution to total biovolume of the algal groups Cyanobacteria (Cyano) and

Bacillariophyta

(Bacillario). All other groups are summarised as Other. Total biovolume as $\mathrm{mm}^{3} \mathrm{l}^{-1}$. Surface area to biovolume ratio $(\mathrm{S} / \mathrm{V})$ as $\mathrm{mm}^{-1}$. Chlorophyll- $a$ as percent of biovolume

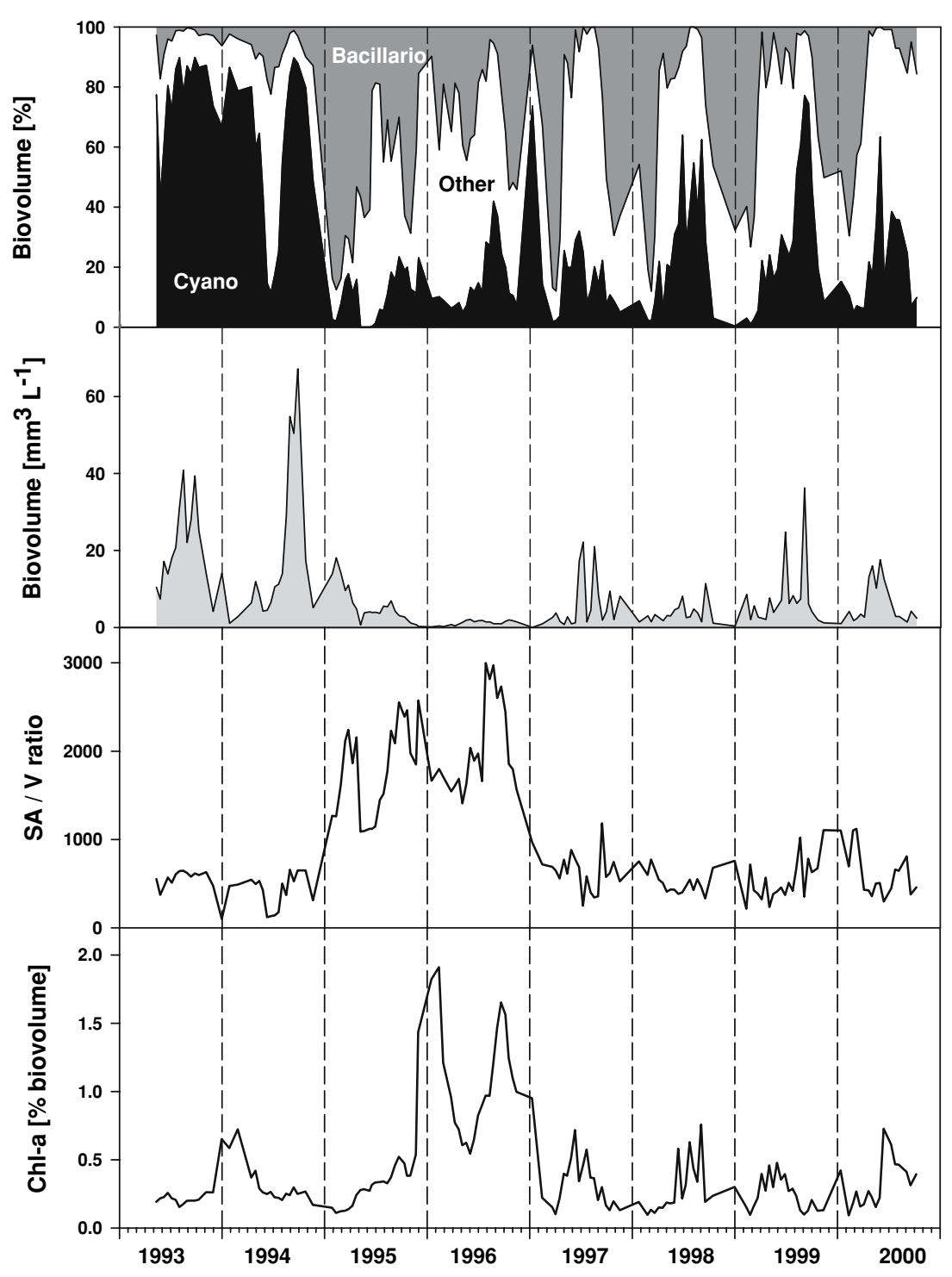

declined from $19 \mathrm{~mm}^{3} \mathrm{l}^{-1}$ to about $1 \mathrm{~mm}^{3} \mathrm{l}^{-1}$ (Fig. 1) and concentration of chlorophyll- $a$ decreased from $43 \mu \mathrm{g} \mathrm{l}^{-1}$ to $12 \mu \mathrm{g} \mathrm{l^{-1 }}$. In 1993 and 1994 the phytoplankton assemblage was dominated up to $90 \%$ by one filamentous cyanobacterial species, Cylindrospermopsis raciborskii seenayya et Subba Raju (Dokulil \& Mayer, 1996). As a consequence of P-reduction, phytoplankton composition completely changed to small sized Bacillariophytes, Chrysophytes, and Chlorophytes. Cyanobacteria remained below 20\% on average during 1995 and 1996 (Fig. 1, top panel). The following years 1997-2000 were characterised by more variable sized species of all algal classes. Significant contributions of small sized cyanobacteria were observed during summer coinciding with biovolume peaks (Fig. 1, top panels).

The change in the size structure of the phytoplankton assemblage is reflected in the surface area to volume ratio $(\mathrm{S} / \mathrm{V})$ as well as in the percentage chlorophyll- $a$ contribution to total biovolume (Fig. 1, lower panels). The $\mathrm{S} / \mathrm{V}$ ratio averaged $470 \mathrm{~mm}^{-1}$ before nutrients were reduced. The ratio rose to an average of about $1,900 \mathrm{~mm}^{-1}$ in 1995 and 1996 when small sized 
species prevailed. In the years after nutrient reduction (1997-2000) S/V fluctuated around a mean of $584 \mathrm{~mm}^{-1}$ (range: $520-644$ ). Total surface area was highly correlated to total biovolume $\left(r^{2}=0.47, P<0.0001, n=265\right)$ while $\mathrm{S} / \mathrm{V}$ declined with increasing biovolume $\left(r^{2}=0.32\right.$, $P<0.0001, n=265$ ).

The frequency distribution of biovolume per cell or filament (Fig. 2, upper panel) indicates on average a three-fold decrease in average biovolume from $600 \mu^{3}$ cell $^{-1}$ (range 200-1,250) when filamentous cyanobacteria dominated to $300 \mu \mathrm{m}^{3}$ cell $^{-1}$ (range 20-550) after species composition had changed. Concomitantly, average $\mathrm{S} / \mathrm{V}$ ratio per cell increased from $25 \mathrm{~mm}^{-1}$ to $350 \mathrm{~mm}^{-1}$. In contrast to the narrow range of $3-55 \mathrm{~mm}^{-1}$ during the Cylindrospermopsis-years, a reflection of the monospecific algal assemblage, the range of $\mathrm{S} / \mathrm{V}$
Fig. 2 Frequency distribution of biovolume per cell (top panel) and S/ $\mathrm{V}$ ratio (lower panel) for the years 1993/1994 (before) and 1995/1996 (after)
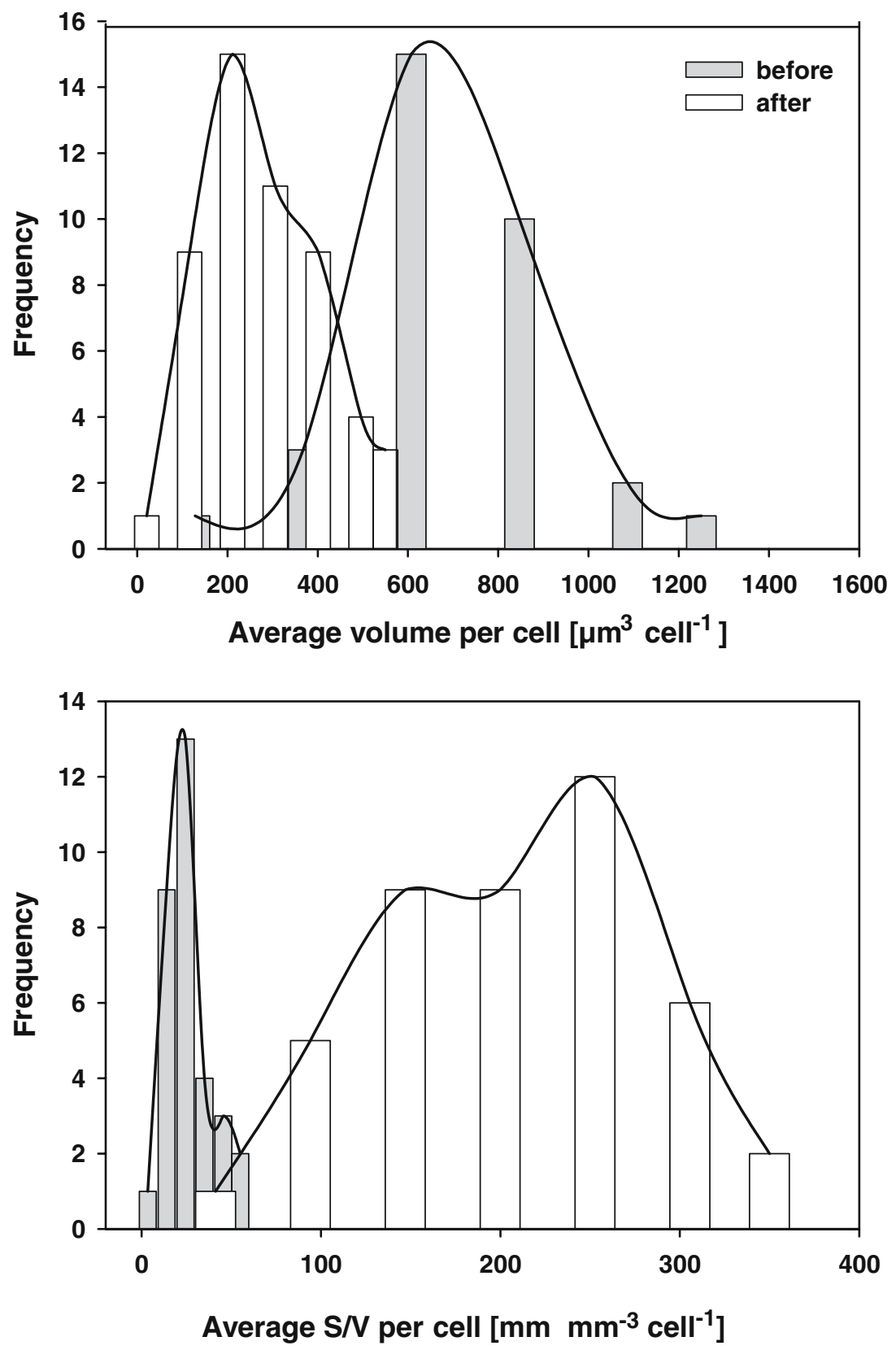


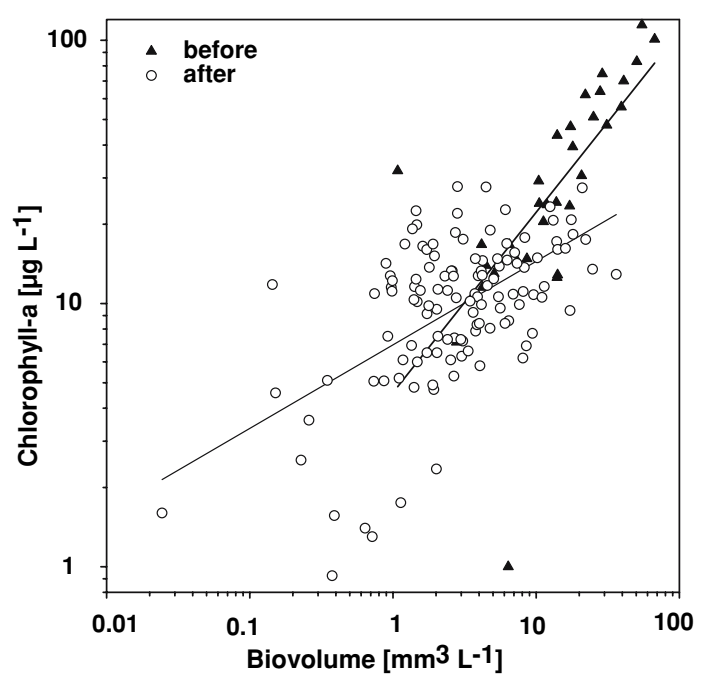

Fig. 3 Log-log regression of biovolume $\left(\mathrm{mm}^{3} \mathrm{l}^{-1}\right)$ against chlorophyll- $a\left(\mu \mathrm{g} \mathrm{l}^{-1}\right)$ for the years 1993/1994 (before) and 1995/1996 (after)
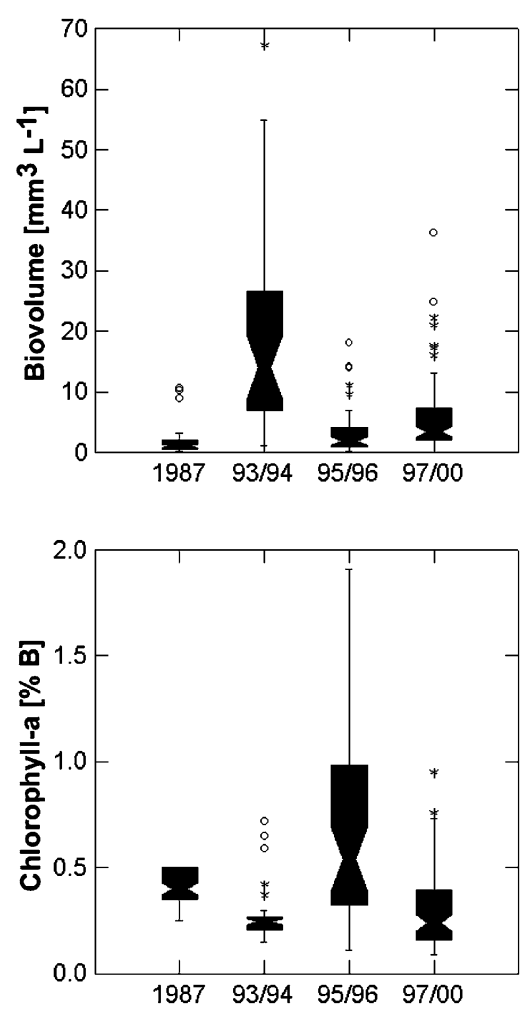

Fig. 4 Notched box-whisker diagrams for biovolume, surface area, percentage chlorophyll- $a$ and $\mathrm{S} / \mathrm{V}$ ratio for the clear water period represented by data from the year 1987, during the turbid state in 1993/1994, after nutrient reduction (1995/1996) and for the recovery years from per cell widened to $40-350 \mathrm{~mm}^{-1}$ when large numbers of small sized species became abundant (1995/1996). In the years after, average cell specific $\mathrm{S} / \mathrm{V}$ ratio dropped to $43 \mathrm{~mm}^{-1}$ but the range remained at 5-400 (data not shown here).

Average contribution of chlorophyll- $a$ to biovolume was $0.28 \%$ when Cylindrospermopsis dominated, rising to $0.72 \%$ during nutrient reduction coinciding with size structure changes (Fig. 1). After the phytoplankton assemblage had stabilised, percentage chlorophyll- $a$ varied around $0.3 \%$ (range $0.25-0.34$ ). Chlorophyll- $a$ was highly related to biovolume before restoration (Fig. 3, $r^{2}=0.84, P<0.001, n=32$ ). After nutrient reduction the relationship became more variable $\left(r^{2}=0.14, P<0.001, n=233\right)$ possibly as a result of year-to-year changes in plankton species composition.
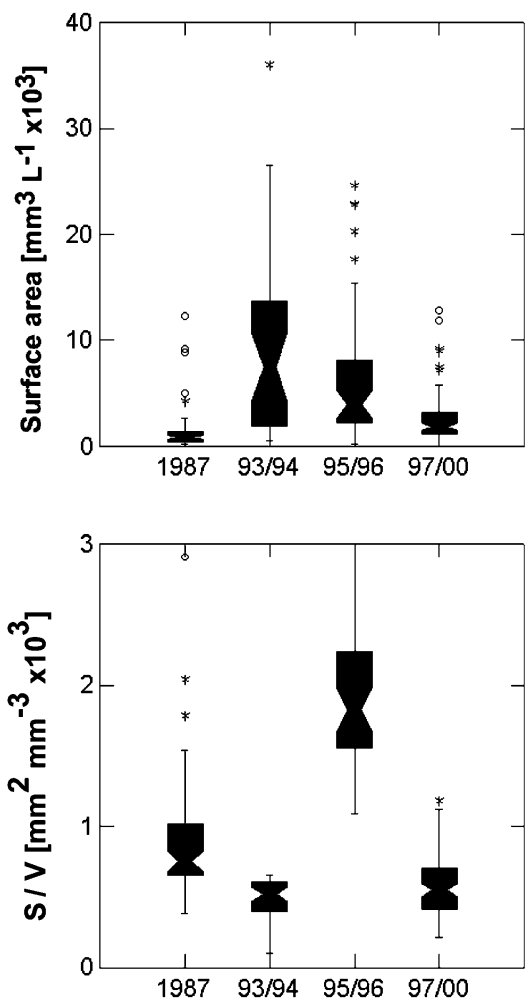

1997 to 2000. The central vertical line marks the median, the notch indicates the confidence interval and the box contains $50 \%$ of all data. Whiskers give the range. Outside values are marked 
Total phytoplankton biovolume and surface area for periods prior to the ecosystem regime shift (1987), during the turbid state (1993/1994), after nutrient reduction (1995/1996) and for the recovery years from 1997 to 2000 are summarised as notched box-whisker plots in Fig. 4 (top panels). Both biovolume and surface area are significantly increased during the turbid, algal dominated state. In contrast to biovolume, which was drastically reduced after restoration, surface area remained high as a consequence of small cell size indicated by the rise in the chlorophyll- $a$ content and the $\mathrm{S} / \mathrm{V}$ ratio (Fig. 4, lower panels).

Similar changes during ecosystem regime shift in the urban lake, Alte Donau have been described for a number of variables and derived parameters by Teubner et al. (2003). Reduction of various nutrient components strongly affected phytoplankton production and growth as well as the producer-consumer interface in the food web.

Here we have shown that state transitions from one stable state to another were associated with significant changes in species composition and size structure of the phytoplankton assemblage. Shifts in either direction altered total biovolume and were accompanied by changes in surface area to volume ratios, percentage share of chlorophyll$a$ and cell size related frequency distribution.

\section{References}

Dokulil, M. T. \& J. Mayer, 1996. Population dynamics and photosynthetic rates of a Cylindrospermopsis-Limnothrix association in a highly eutrophic urban lake, Alte Donau, Vienna, Austria. Algological Studies 83: 179195.

Dokulil, M. T., K. Donabaum \& K. Pall, 2006. Alternative stable states in floodplain ecosystems. Ecohydrology \& Hydrobiology (in press).
Dokulil, M. T., K. Teubner \& K. Donabaum, 2000. Restoration of a shallow, ground-water fed urban lake using a combination of internal management strategies: a case study. Archiv für Hydrobiology, Special Issue Advances in Limnology 55: 271-282.

Donabaum, K., K. Pall, K. Teubner \& M. T. Dokulil, 2004. Alternative stable states, resilience and hysteresis during recovery from eutrophication - a case study. SIL-news 43: 1-4 (http://www.limnology.org/news/silnews43.pdf).

Finkel, Z. V., A. J. Irwin \& O. Schoffeld, 2004. Resource limitation alters the $\frac{3}{4}$ size scaling of metabolic rates in phytoplankton. Marine Ecology Progress Series 273: 269-279.

Havlicek, T. D. \& S. R. Carpenter, 2001. Pelagic species size distribution in lakes: are they discontinuous? Limnology and Oceanography 46: 1013-1020.

Joint, I., 1991. The allometric determination of pelagic production rates. Journal of Plankton Research 13(Suppl.): 69-81.

Lewis, W. M. Jr., 1977. Net growth rate through time as an indicator of ecological similarity among phytoplankton species. Ecology 58: 149-157.

Moloney, C. L. \& J. G. Field, 1989. General allometric equations for rates of nutrient uptake, ingestion, and respirations in plankton organisms. Limnology and Oceanography 34: 1290-1299.

Nielsen, S. L. \& K. Sand-Jensen, 1990. Allometric scaling of maximal photosynthetic growth rate to surface/ volume ratio. Limnology and Oceanography 35: 177181.

Shkundina, F. B., 1991. Classification of phytoplankton in terms of size and morphology. Gidrobiologiecheskiy zhurnal 27: 42-46.

Teubner, K. \& M. T. Dokulil, 2000. Seasonal dynamic of surface:volume-ratio of phytoplankton assemblages. Verhandlungen der Internationalen Vereinigung für Theoretische und Angewandte Limnologie 27: 2977-2978.

Teubner, K., N. D. Crosbie, K. Donabaum, W. Kabas, A. K. T. Kirschner, G. Pfister, M. Salbrechter \& M. T. Dokulil, 2003. Enhanced phosphorus accumulation efficiency by the pelagic community at reduced phosphorus supply: a lake experiment from bacteria to metazoan zooplankton. Limnology \& Oceanography 48: 1141-1149. 